\title{
Chapter 33 \\ Iron and Calcium Biomineralizations in the Pampean Coastal Plains, Argentina: Their Role in the Environmental Reconstruction of the Holocene
}

\author{
Margarita Osterrieth, Celia Frayssinet, and Lucrecia Frayssinet
}

\begin{abstract}
Biomineralizations are biogenic composites, crystalline or amorphous, produced by the metabolic activity of organisms distributed all over the world. The aim of this work was to evaluate the presence of iron and calcium biomineralizations and their influence in the physicochemical and mineralochemical variations in paleo and actual pedosedimentary sequences of the coastal plains in Mar Chiquita. The complex interaction of calcium with iron biomineralizations, as framboidal and poliframboidal pyrites associated with gypsum, barite, calcite, halite, and iron oxyhydroxides, have demonstrated the active and complex biogeochemistry that occurs in the temperate-wet paleoesturaries and estuaries of the coastal Pampean Plains. Particularly the consequences that different human activities could have, such as the possible acidification processes as result of the iron sulfide oxidation.
\end{abstract}

Keywords Framboidal pyrite $\cdot$ Poliframboidal pyrite $\cdot$ Calcium oxalate $\cdot$ Calcite Biogeochemistry $\cdot$ Soil acidification

\subsection{Introduction}

Biominerals are deposited in intra- or extracellular spaces as the consequence of metabolic activity. Biomineralizations processes are genetically controlled and are also a widespread phenomenon in nature that can take place on both marine and terrestrial systems, acting as a global source and sink of soluble ions (Lowenstam 1981; Osterrieth 2004). Among the most common biomineralizations can be mentioned those ones composed by calcium, iron, and amorphous silica (Mann 2001),

\footnotetext{
M. Osterrieth $(\varangle) \cdot$ C. Frayssinet $\cdot$ L. Frayssinet Instituto de Geología de Costas y del Cuaternario (IGCyC), FCEyN, UNMdP - CIC, Mar del Plata, Argentina

Instituto de Investigaciones Marinas y Costeras (IIMyC), CONICET - UNMdP, Mar del Plata, Argentina
} 
particularly in coastal environments, where the interaction between marine and terrestrial processes is very intense, as well as the biotic and anthropic activity.

The geomorphological and biotic factors in concordance with the pedological processes have created a complex soil system, where the active iron and calcium biogeochemistry might allow the acidification processes, as result of the iron sulfide oxidation, when biogenic calcium is available (Osterrieth et al. 2017).

In Argentina, the first record about framboidal pyrites biomineralizations associated with paleo-salt marshes environments dates from 1992 (Osterrieth 1992), without further information, while in other regions, there is a large number of reports about the pyrites formation and its biogeochemical implications (Stribling 1997; Wilkin et al. 1996; Roychoudhury et al. 2003).

The research of calcium biomineralizations at pedesodimentary sequences associated to bioclastic levels and bioerosion processes is very scarce in Argentina (Osterrieth et al. 2000, 2016, 2017).

In the Pampean plains, coastal morphodynamics throughout the Holocene (10,000 BP until now) have been very active and have produced variations linked to the installation of coastal barriers, conditioning the evolution of dunes, marshes, and the unique coastal lagoon of Argentina: Mar Chiquita lagoon (Osterrieth 2005).

The aim of this work was to evaluate the presence of iron and calcium biomineralizations and their influence in the physicochemical and mineralochemical variations in paleo and actual pedosedimentary sequences of the coastal plains in Mar Chiquita, Argentina.

\subsection{Materials and Methods}

\subsubsection{Study Site}

Study site is located in the coastal area of Mar Chiquita, Buenos Aires province (Fig. 33.1).

The regional weather is mesothermic and subhumid. The vegetation is characterized by communities of psammophytic, halophytic, and freshwater plants, as well as by woodlands. The main soils at the study area are Udolls and Aquents (Osterrieth 2005).

\subsubsection{Methods}

The soils and exhumed soils were analyzed across a coastal section of $10 \mathrm{~km}$ length (Fig. 33.1); description of the modal profiles was reported according Soil Survey Staff (1996). Different pedosedimentary sequences of the Holocene present in geomorphological units (UG): paleoestuarine (UG1) and estuarine-salt marsh (UG2) were analyzed (Fig. 33.1a, b). 


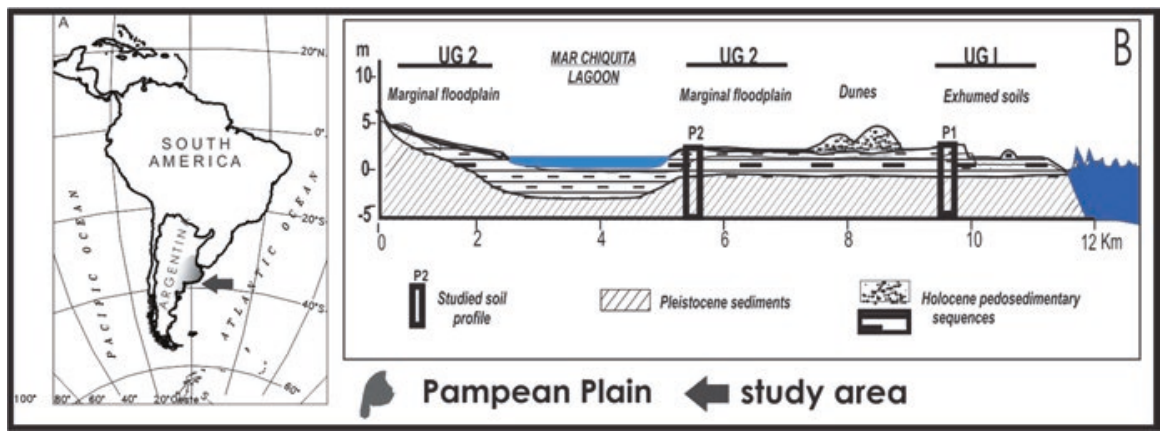

Fig. 33.1 Study area. Toposequence, geopedological units (UG1, UG2), and profiles studies (P1-P2)

Dating by ${ }^{14} \mathrm{C}$ acceleration mass spectrometry (AMS) was performed (Beta Analytic, USA; LATIR-UNLP) on soil organic matter and bioclastic material.

Organic matter content, $\mathrm{pH}$, calcium carbonate, and particle size distribution were done by routine methods (Walkley and Black 1965; Dawis 1970; Galehouse 1971, respectively).

Disturbed and undisturbed samples at different scales of resolution were analyzed using polarization microscope (Olympus BX 51P) and scanning electron microscope (SEM: JEOL JSM6460LV). Mineralochemical studies were performed using an energy dispersive X-ray spectrometer (EDXS, between 15 and $25 \mathrm{kV}$ ).

\subsection{Results and Discussion}

Mar Chiquita region is mostly included in the Biosphere Reserve (Man and Biosphere Reserve Program, UNESCO) called "Parque Atlántico Mar Chiquita" (UNESCO 2016). This reserve is a coastal ecosystem with specific organism diversity and, affected by complex biogeochemical processes, is a shallow body of brackish water affected by low amplitude tides and constitutes an estuarine environment with a very particular behavior (Marcovecchio et al. 2006). The morphodynamics of this area is unique as marine, estuarine, and eolian deposits interdigitate and intercalate between them (Osterrieth 2005).

\subsubsection{Paleoestuarine: Exhumed Soils (UG1)}

\subsubsection{Morphological and Physicochemical Characteristics}

The exhumed soils were affected by an active erosion and showed diagenetic and biogeochemical specific characteristics associated with ancient coastal deposits, linked to the last Holocene transgressive-regressive cycle (Fig. 33.2a, b, d-1). Soils 

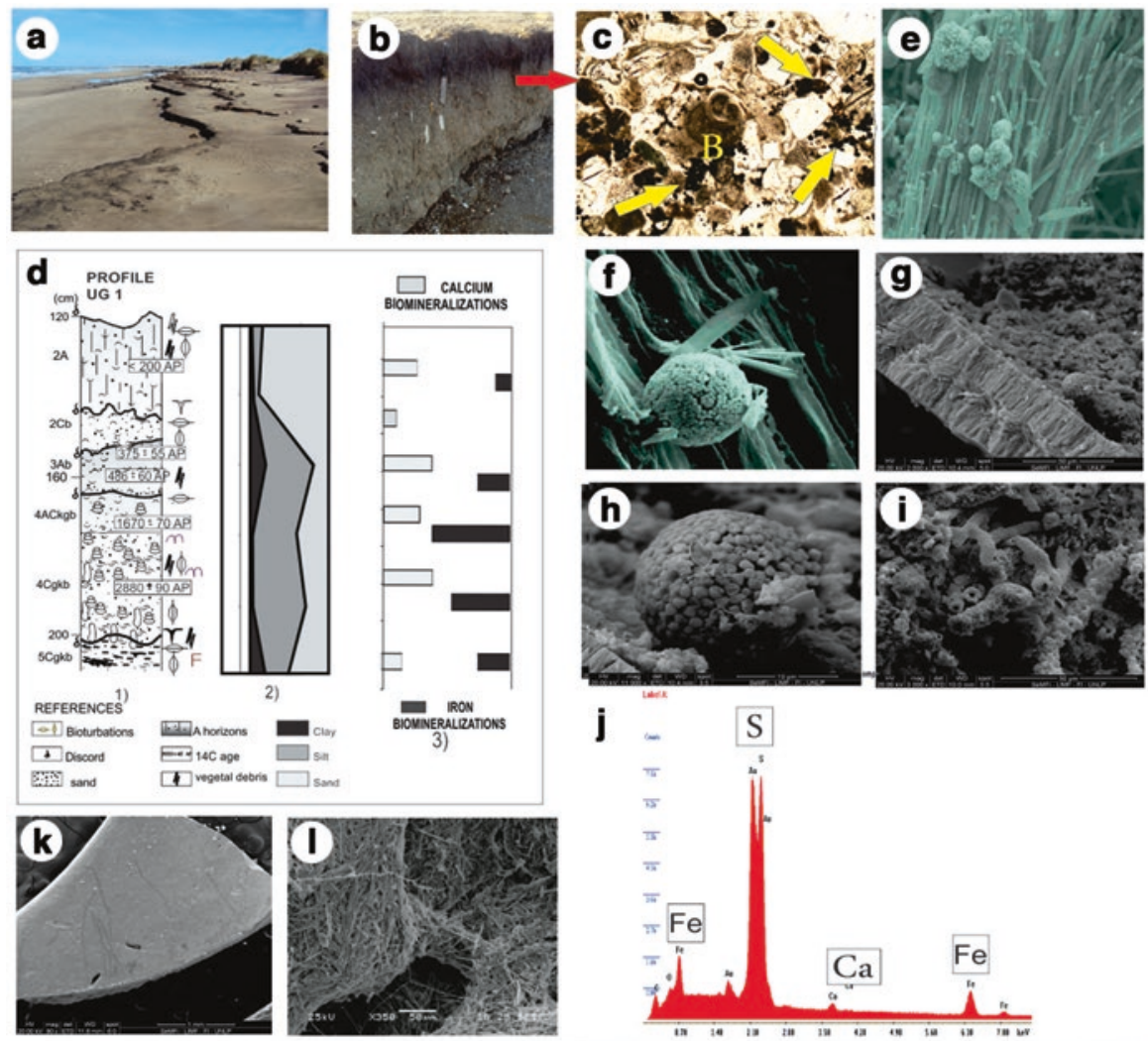

Fig. 33.2 (a) Panoramic view of the exhumed soils (UG 1). (b) Photo of del modal profile. (c) Micromorphological photo (3Ab). (d) Geological profile, grain size analysis, and biomineralizations present in the profile. (e) Framboidal pyrites and gypsum in the soil matrix. (f) Framboidal pyrites, gypsum, and barite on vegetal debris, (g) associated with bioclast. (h) Detailed view of framboidal pyrites. (i) Tubes calcium biomineralizations (CB) in matrix soil. (j) EDXS result of soil matrix, in the profile, (k) bioclast bioeroded. (I) CB on clast and matrix exhumed soil. BC: bioclasts. Yellow arrow: framboidal pyrites (FP). e-l: SEM photos

were characterized as Hapludolls (2A-2Cb horizons), Sulfaquents ( $3 \mathrm{Ab}$ and $4 \mathrm{ACkgb}-4 \mathrm{Cgkb}$ horizons), and Fluvaquents (5Cgkb horizons), all of them with low to moderated pedological development (Fig. 33.2d-1).

At the subsuperficial horizons, $\mathrm{pH}$ values were alkaline (8-9), as consequence of the saline and/or brackish water influence, with high exchangeable sodium contents and with abundant bioclastic materials that were affected by processes of bioerosion and calcium carbonates and oxalates reprecipitation (Fig. 33.2k) (Osterrieth 2005). The superficial horizon was slightly alkaline to neutral (7-8) due to the high organic matter content. The grain size distribution showed a sandy texture in $2 \mathrm{~A}$ level, changing to silt loam towards the bottom of the profile. In all the exhumed soils, the clay content was very scarce (Fig. 33.2d). 
The organic matter content was medium (between $6 \%$ and 10\%) and has decreased with depth.

Carbonates were present in all the profile, as whole or fragmented shells, scattered in the soil mass. The calcium carbonate content was variable and increased toward the lower horizons, with an average between $6 \%$ in $2 \mathrm{~A}$ and $15 \%$ in $2 \mathrm{Cb}, 3 \mathrm{Ab}$ horizons, but rising to more than $35 \%$ in paleosols (level 4 and 5), associated with bioclastic materials.

\subsubsection{Iron and Calcium Biomineralizations}

Previous research on exhumed paleo marshes have determined that the iron content was between 56 and $95 \mu \mathrm{mol} \mathrm{Fe/g}$ and have reflected that the largest iron proportion was in the form of crystalline iron oxides (28-76\%) and lepidocrocite (6-16\%), while the proportion associated with ferrihydrite and pyrite was lower (0-9\% and $1-17 \%$, respectively), especially at the upper levels of the exhumed soils (2A and $3 \mathrm{Ab}$ in Fig. 33.2d-1). According with the chemical fractionation data on these horizons, well defined framboidal pyrites were found associated with the plant debris cover (Fig. 33.2d-3, j). These pyrites increased in quantity and morphological variety toward the bottom of the profile, where the anoxic conditions were more resistant (Osterrieth et al. 2016).

The presence of framboidal and poliframboidal pyrites associated with gypsum, barite, calcite, halite (Fig. 33.2c, e-h), and iron oxyhydroxides was frequent all along the profile. The sequences of pyrite formation (sulfidation) as well as their metastable forms (mackinawite and greigite) were observed. Framboidal pyrites showed diverse morphologies: combined microcrystals, octahedral-dodecahedral subedrals, and cubic and irregular octahedral microcrystals subedrals to anedrals with sizes between 0.2 and $5 \mu \mathrm{m}$, closely associated with plant debris, bioclasts, and pores and channels of the soil matrix (Fig. 33.2g, h). Degradation processes (sulfurization) were inferred by geochemical and EDXS results, as presence of crystalline iron oxides, lepidocrocite, and ferrihydrite were observed immersed in the matrix of the peds. This sulfurization was related to the complex redox processes of these environments, such as the aeration that is generated in the rhizosphere and also by the intense bioturbation of invertebrates (Osterrieth et al. 2016). Once the sequence was exposed to oxic conditions and eroded by storm episodes, the oxidation of sulfides and the intense dissolution and transformation of framboidal pyrite into iron crystalline phases could have been the responsible for the acidic conditions, mainly in the surface horizons (Roychoudhury et al. 2003)

The association of framboidal pyrites have originated elongated and subspherical poliframboidal pyrites, with sizes of 50-80 $\mu \mathrm{m}$ wide and 190-140 $\mu \mathrm{m}$ length. They were immersed and cemented by thin films of amorphous silica and iron (Fig. 33.2c). These secondary framboidal pyrites were authigenic, generated "in situ" under anoxic conditions (Osterrieth 1992). The framboidal pyrite genesis in these coastal soils of the Pampean Plain was bacterial, through biogeochemical reduction processes that 
have produced a certain type of microcrystals, very different from those generated by purely chemical action (Osterrieth et al. 2016; Wilkin et al. 1996).

A lot of isolated octahedral and dodecahedral pyrite's crystals associated with framboids and with different types of biofilms, mainly composed by silica were observed. These biofilms might be related to the high amounts of diatoms and silicophytoliths found that could have been altered by the extreme $\mathrm{pH}$ values consequence of the framboidal pyrites generation and degradation cycle.

These paleoestuarine deposits, with abundant wholly and partially fragmented bioclasts, included mollusk shells such as Heleobia sp., dated 1,670 \pm 70 year BP by ${ }^{14} \mathrm{C}$, and Tagelus plebeius dated between 1,710 \pm 60 and 2,880 \pm 90 year BP (Osterrieth, 2005). Also, soil organic carbon was dated, ranging from $<200$ year BP to $486 \pm 60$ year BP.

This bioclastic material constituted by calcite/aragonite biomineralizations was affected by dissolution, bioerosion (Fig. 33.2k), and reprecipitation of biogenic calcium carbonates and oxalates (bacteria, fungi, and algae). The reprecipitation processes were relevant on the bioclasts (Fig. 33.2i, 1) and in the matrix between grains and bioclasts (Fig. 33.21). The matrix of the peds had dense calcified filaments, raphides, styloids, tubes, rods, and short and long needles with sharp or straight ends, composed by whewellite (monohydrate calcium oxalate) or weddellite (polyhydrated calcium oxalate) (Fig. 33.2i, 1) (Verrecchia and Verrecchia 1994, Verecchia et al. 1995; Osterrieth et al. 2000, 2017). In general, all the morphologies found here could be associated with microbial activity at the matrix, coating peds, pores, and the bioclastic-matrix interface (Fig. 33.2i, 1). Moreover, it was common to see framboidal pyrite associated to bioclasts, being part of a complex biofilm composition dominated by calcium (41\%), chlorine (29\%), silica (13\%), carbon (5\%), iron (5\%), sodium (4\%), and aluminum (3\%) (Fig. 33.2j).

\subsubsection{Estuarine Actual Soils (UG2)}

\subsubsection{Morphological and Physicochemical Characteristics}

The soils (Profile 2) were located within the marginal plain and the tidal channels of the Mar Chiquita lagoon (Fig. 33.1b) affected by the lagoon's level variation and also by the episodic sea advances that had increased the presence of iron sulfides in the surface. These soils classified as oxyaquic Udifluvents (Fig. 33.3b) were affected by the presence of mollusk shells and intensely bioturbated by Uca uruguayensis and Neohelice granulate (Fig. 33.3).

The vegetation community was composed of Cortaderia selloana, Panicum racemosum, Sacocornia sp., Juncus sp., etc. (Fig. 33.3a, b). 

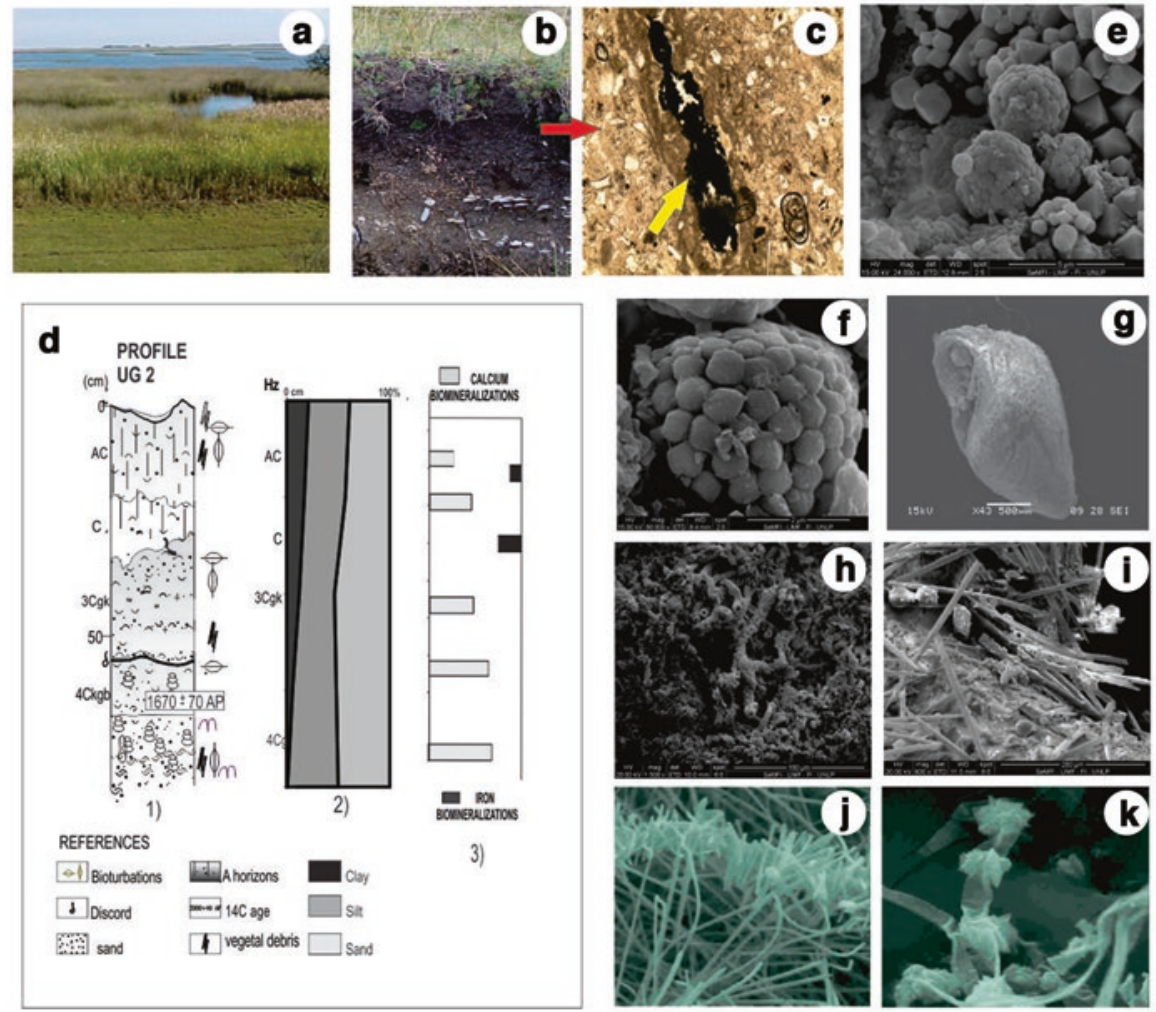

Fig. 33.3 (a) Panoramic view of the UG2. (b) Photo of del modal profile (P2). (c) Micromorphological slide (AC). (d) Geological profile, grain size analysis, and biomineralizations in the profile. (e) Framboidal pyrites in and isolates pyrite crystals in the marsh soil matrix. (f) Detailed view of framboidal pyrites. (g) Heleobia sp. bioeroded; (h) SEM, soil matrix with CB; (i) matrix with filaments, rods $\mathrm{CB}$; (j) detailed view of $\mathrm{CB}$ : rods, raphides, and styloids associated with the bacterium; (k) detailed view of rosettes $\mathrm{CB}$ associated with fungi. Yellow arrow: framboidal pyrites (FP). (e-k): SEM photos

Soil reaction ranged from moderately alkaline in the surface to alkaline at the base of the sequence ( $\mathrm{pH}: 7.5-9)$. The organic matter content was moderate in the AC horizon $(6.5 \%)$ and has descended sharply toward the bottom of the profile (1.3\%). The calcium carbonate content was scarce $(6 \%)$ in the superficial horizon (AC) and increased at the lower horizons (3Cgk and $4 \mathrm{Cgkb}$ horizon) associated with the presence of bioclastic materials (33\%).

The sequence was texturally homogeneous with fine and very fine sand fractions being dominant, while the AC horizon showed a slight increase in clays and silts (Fig. 33.3d-2). 


\subsubsection{Iron and Calcium Biomineralizations}

In these soils the presence of iron and calcium biomineralizations was common too, but the framboidal and poliframboidal pyrites were less abundant when compared to the paleoesturine soils. The quantity and morphologies of the calcium biomineralizations observed in this profile were similar to those registered in UG1.

The low degree of pyritization registered here, which is below the typical values reported for modern estuarine sediments of tropical environments (Wilkin et al. 1996), could be explained by the lower proportion of iron obtained here (36-75 $\mu \mathrm{mol}$ $\mathrm{Fe} / \mathrm{g}$.) (Osterrieth et al. 2016). The sequences of pyrite formation (sulfidation) were observed with diverse morphologies, for example, octahedral-dodecahedral microcrystals and irregular octahedral microcrystals subedrals to anedrals (Fig. 33.3c, f). The presence of gypsum or barite associated to framboidal pyrites was very scarce, although the oxic conditions were more common in this soils than in the paleomarisms.

In these soils, the aeration generated by the high density of crab burrows and $S$. densiflora has promoted the oxic conditions that leaded to a lower pyrite framboidal production (Osterrieth et al. 2016).

Bioclasts were affected by bioerosion through the action of microorganisms with a subsequently calcium reprecipitation as secondary oxalates and carbonates biomineralizations (Fig. 33.3g-k). These biomineralizations were also added or weakly bound to the skeletal components, which allowed them to be incorporated into the matrix of soils and sediments. Mineralochemical studies confirmed the presence of calcium and variable carbon contents, subject to the crystal's development stage. Thus, it was possible to define the genetic sequence of calcite via calcium oxalate (weddellite and whewellite) associated with hyphae, algae, soil bacteria, and actinomycetes. A remarkable variety of dichotomous tubes was found as clear evidence of fungal genesis, added to elongated tubes of multiple sizes and diameters, and complex interdigitated crystalline textures of oxalate and calcium carbonates, that also indicated biological production (Fig. 33.3g-k). Type and diversity of calcium biomineralizations increased directly in relation with the bioclastic parental material and biogeochemical conditions (Fig. 33.3d-3).

\subsection{Final Remarks}

The important role of the iron and calcium biomineralizations lies on the possibility to further understand the biogeochemical processes and to deepen the knowledge about the complex interaction of the pedological processes on the paleo and recent coastal environments. They also allow us to deduce that many environmental processes do not correlate with chronological evolution, while biogeochemical aspects related to biomineralizations do.

The presence of iron biominerals allowed us to define the redoxymorphic conditions in paleoestuarine and estuarine pedosedimentary sequences. 
Calcium biomineralizations were found and associated with processes of dissolution and reprecipitation of calcium carbonates and oxalates associated to fungus, algae, and bacteria in actual and exhumed soils.

Calcium and iron biomineralizations with other cations and organic components allowed the formation of organomineral complex which plays an important role in the availability of macro- and micronutrients for the biota development and in the persistence of the aggregates and the resistance to erosion processes in these coastal soils.

Iron and calcium biomineralizations found in paleo marshes allow us to make inferences related to the management of actual salt marshes, warning us about the possible acidification processes generated by the iron sulfide oxidation associated to different human activities in the temperate-wet coastal environments of the Pampean Plains.

Acknowledgments This work was supported by the AGENCIA-PICT 1583/2013, UNMDPEXA 741/15, and CONICET- PIP-11220130100145CO.

\section{References}

Dawis JF (1970) Physiological and chemical methods of soil and water analysis. Soil Bull 10:39-51 Galehouse JS (1971) Sedimentation analysis. In: Carver (ed) Procedures in sedimentary petrology. Wiley Interscience, Hoboken, pp 69-94

Key facts and figures on Argentina - UNESCO cooperation (2016) Available in; https://es.unesco. org/system/files/countries/Home/arg_facts_figures.pdf?language

Lowenstam HA (1981) Minerals formed by organisms. Science 211:1126-1131

Mann S (2001) Biomineralization: principles and concepts in bioinorganic materials chemistry. Oxford University Press, New York

Marcovecchio J et al (2006) Seasonality of hydrographic variables in a coastal lagoon: Mar Chiquita, Argentina. Aquat Conserv Mar Freshwat Ecosyst 16:335-347

Osterrieth M (1992) Pirita framboidal en secuencias sedimentarias del Holoceno tardío en Mar Chiquita, Buenos Aires, Argentina. IV R Arg de Sedimentol 2:73-80

Osterrieth M (2004) Biominerales y Biomineralizaciones. In: Sociedad Mejicana de Cristalografía (eds) Cristalografía de Suelos, pp 206-218

Osterrieth M (2005) Biomineralizaciones de hierro y calcio, su rol en procesos biogeoquímicos de secuencias sedimentarias del sudeste bonaerense. XVI Congreso Geol Argent III:255-262

Osterrieth M et al (2000) Biominerales de oxalato de calcio en suelos de Laguna de los Padres, Buenos Aires. Rev Argent Cienc del Suelo 18(1):50-58

Osterrieth $\mathrm{M}$ et al (2016) Iron biogeochemistry in Holocene palaeo and actual salt marshes in coastal areas of the Pampean plain, Argentina. Environ Earth Sci 75:671-672

Osterrieth M, et al. (2017) Calcium Biomineralizations associated with bioclastic deposits in coastal pedostratigraphic sequences of the Southeastern Pampean Plain, Argentina. In: Rabassa $\mathrm{J}$ (ed) Advances in geomorphology and quaternary studies in Argentina, vol 11. Springer, Cham, pp 261-287

Roychoudhury A et al (2003) Pyritization: a palaeoenvironmental and redox proxy reevaluated. Estuar Coast Shelf Sci 57:1183-1193

Soil Survey Staff (1996) Keys to soil taxonomy, 7th edn. United States Department of Agriculture, Washington, DC 
Stribling J (1997) The relative importance of sulfate availability in the growth of Spartina alterniflora and Spartina cynosuroides. Aquat Bot 56:131-143

Verrecchia E, Verrecchia K (1994) Needle-fiber calcite: review and classification. J Sediment Res 64(3):650-664

Verrecchia E et al (1995) Role of calcium oxalate biomineralization by fungi in the formation of calcretes: a case study from Nazareth, Israel. J Sediment Petrol 65:1060-1066

Walkley A, Black A (1965) In: Black C (ed) Methods of soil analysis. American Society of Agronomy, Madison, pp 1372-1375

Wilkin RT et al (1996) The size distribution of framboidal pyrite in modern sediments: an indicator of redox conditions. Geochim Cosmochim Acta 60(20):3897-3912

Open Access This chapter is licensed under the terms of the Creative Commons Attribution 4.0 International License (http://creativecommons.org/licenses/by/4.0/), which permits use, sharing, adaptation, distribution and reproduction in any medium or format, as long as you give appropriate credit to the original author(s) and the source, provide a link to the Creative Commons license and indicate if changes were made.

The images or other third party material in this chapter are included in the chapter's Creative Commons license, unless indicated otherwise in a credit line to the material. If material is not included in the chapter's Creative Commons license and your intended use is not permitted by statutory regulation or exceeds the permitted use, you will need to obtain permission directly from the copyright holder. 